\title{
SAVING AND REAL INTEREST RATES IN BRAZIL
}

\author{
By Daniel Luiz Gleizer*
}

\section{Resumo}

Este artigo apresenta uma análise crítica do esforço do governo em aumentar a poupança nacional e a poupança privada através do aumento da taxa de retorno real dos ativos financeiros. Usando a economia brasileira como estudo de caso, argui-se que o sucesso em aumentar a taxa de poupança tem sua origem na reforma fiscal que acompanhou o processo de reforma do sistema financeiro que procurou liberar as taxas de juros de controles administrativos. Dois tipos de exercícios econométricos são realizados para estudar a sensibilidade da poupança a mudanças na taxa de juros real esperada. O primeiro exercício faz uso de uma função de poupança clássica para avaliar a magnitude da elasticidade da poupança em relaçào a taxa de juros. O segundo teste aborda o problema através da equação de Euler e mede a taxa de substituição intertemporal do consumo. Os resultados obtidos em ambas as seçōes mostram que o efeito da taxa de juros real sobre a poupança agregada privada é negligivel. Estes resultados tem implicaçōes profundas para os programas de estabilização e de reforma estrutural pois contradizem a hipótese comportamental fundamental subjacente à política de poupança recomendada para os países em desenvolvimento por organizaçōes internacional tais como o Banco Mundial e o FMI.

\begin{abstract}
This paper presents a critical analysis of governments' attempts to increase national and private savings by raising the real rate of return on financial assets. Using the Brazilian economy as a case study, the paper argues that successes in increasing the savings rate can be traced to the fiscal reforms that accompanied the process of financial system redesign that sought to free interest rates from administrative controls. Two types of econometric exercises are performed to offer evidence of the responsiveness of savings to changes in the expected real interest rate. The first one uses a standard saving function approach in evaluating the magnitude of the interest elasticity of savings. The second test addresses the issue by using the Euler equation technique and measuring the rate of intertemporal substitution in consumption. The results obtained in both sections point to a negligible effect of real interest rates on aggregate and private sector saving. These results have important implications for the design of stabilization and structural reform programs and they contradict the fundamental behavioral
\end{abstract}

*International Monetary Fund, Washington D.C. 20433 - USA

\begin{tabular}{llll}
\hline R. de Econometria & Rio de Janeiro & v. XI, ne 1, p.63-92 abril 1991
\end{tabular}


hypothesis underlying the savings policy advice most often given to developing economies by international organizations like the World Bank and the IMF.**

\section{Introduction.}

This essay studies the effects of interest rates on domestic and private savings in the Brazilian economy since 1960. It is organized as follows: Section 2 presents a short revicw of the theoretical and empirical issues discussed in the macrocconomics literature, in general, and in the development literature in particular. Section 3 discusses the Brazilian experience since 1960, presenting the reforms of the financial system undertaken in the mid-sixties and stressing the important role of indexation as a way of freeing interest rates in the presence of administrative controls and high inflation. In the fourth section a series of econometric tests are performed in order to assess the responsiveness of savings to changes in the real intercst rate. The tests fall into two groups: Conventional saving function tests and Euler Equation tests. The first group is the standard approach in the Economic Development literature, whereas the second type is more characteristic of recent Macroeconometric studies in developed economies. Section five concludes. The definitions and sources of the data series used are presented in an appendix.

\section{A cursory literature review.}

The rate of interest has always been considered a possible variable explaining the saving behavior of individuals. After a Keynesian interlude during which the level of income was regarded as the main determinant of savings, the rate of interest came back to the center of the discussion, mainly through theories of saving (consumption) behavior based on utility maximization, given the present value of

** This paper is a modified version of a chapter of my Ph.D. dissertation, in progress at the Department of Economics of the University of California, Berkeley. I would like to thank Albert Fishlow for his guidance and advice. Additional than'ss are due Afonso Bevilaqua, Ariel Fiszbein, William Maloney, Ana Novaes, Demosthenes Pinho, Richard Sutch and James Wilcox for useful comments.

The paper was written and submitted while the author was a $\mathrm{PhD}$ student at Berkeley. The findings, interpretations and conclusions expressed in this article are those of the author and do not necessarily represent the views and policies of the International Monetary Fund. 
lif etime resources. Standard microeconomic theory shows that an increase in the rate of interest will have an overall effect on savings which depends on the relative importance of two partial effects: a substitution effect that makes saving more attractive and an income effect that reduces the amount of saving required in order for any target future wealth to be reached. Despite agreement on the theoretical effect of interest rates on savings, there is considerable disagreement as to the empirical evidence, a point to which I will return later.

In the development literature the presumed positive effects of interest rates on savings became the cornerstone of the financial sector and savings policy advice most of ten given to developing countries: raise real interest rates. One of the main focuses of such work is on the effects of infiation on savings in countries where the government pegs nominal interest rates. Indeed, according to what became known as the "Financial Repression" (FR) literature", the main cause of the insufficient level of savings that characterizes the less-developed economies (LDC's) is the widespread use of government controls on interest rates and in particular controls which result in negative real in terest rates on deposits, and controls that create segmented and inefficient credit markets. The prevailing negative real in terest rates in such economies discourage savings, constricting the supply of funds to the banking sector. The alleged effects of FR are, on the one hand, a reduction in the level of productive investment due to credit rationing and, on the other hand, a reduction in the average efficiency of the investment projects undertaken, since projects which yield returns barely above the ceiling in terest rate are often financed. That is, repression gives rise to inefficient credit allocation due to the use of non-market rationing mechanisms. The policy prescriptions originated from these studies are those of raising the institutional real interest rates and an avoidance of inflation. The alleged result is an increase in the amount of savings forthcoming, leading to higher and more efficient investment. That is, abolishing interest rate ceilings would produce the optimal results of increasing savings, maximizing

\footnotetext{
IFR theories originated with Mckinnon (1973) and Shaw (1973), and were later elaborated by Galbis (1977), Fry (1980) and, Kapur (1976) among others. Fry (1988) surveys the original contributions, subsequent theoretical refinements and the available empirical evidence.
} 
investment and raising investment's average efficiency. ${ }^{2}$

The financial liberalization prescription of high deposit rates as the proper strategy to increase investment and growth has been challenged by many authors, mostly writing from a neo-structuralist perspective. One set of models emphasized the perverse inflationary effects of higher interest rates (the so-called Cavallo effect), because of higher working capital costs (Van Wijbergen 1983a). Increased inflation is accompanied by recession if the interest elasticity of savings is close to zero. Another group of models emphasize the role of curb markets. Van Wijbergen shows that higher deposit rates can be stagflationary if they induce a shift out of an asset providing more intermediation than the banking system, such as loans in a curb market. Yet another set of models (Taylor 1983) calls attention to the implicit assumption of the FR literature that the portfolio shift into financial savings is coming out of unproductive assets, such as gold, cash etc. Taylor argues that raising real interest rates is not recommended if the "gold" asset is not easily renounced when bank deposits go up. Finally, the menu of assets in FR models is restricted to cash and deposits in the domestic banking system and, in some models to consumer durables. The existence of alternative assets, such as internal government debt, introduces the possibility of high interest rates leading to dynamic instability, as in Fishlow and Morley (1985). ${ }^{3}$

It is worth noting that the importance of the FR literature has reached far beyond academic work. Its policy prescriptions are now a major component of the stabilization and development plans sponsored by the IMF and by the World Bank and, in fact, represent the main approach to savings policy used in the last decade. Financial liberalization experiments were attempted in many Latin American countries, with distressing results. Not only did aggregate savings not increase, but the experiments resulted in major financial crises. The title of an essay by a prestigious obscrver of the region's economies is rather suggestive: "Good-bye Financial Repression, Hello Financial Crash". (Diaz- Alejandro, 1985).

\footnotetext{
${ }^{2}$ Fry (1980) calculates that a point rise in real deposit rates could raise the rate of growth of GDP $1 / 2$ percent per year. An enormous, and evidently questionable, effect. Similar claims are made by the World Bank in its 1987 World Development Report.

${ }^{3}$ See Welch (1988) and Fry (1988) for extensive literature reviews.
} 
Given the crucial role played by the elasticity of savings with respect to the real interest rate, a large number of empirical papers on the subject have appeared. This is a crucial point because, as mentioned above, the eff ect of higher interest rates on savings is not clear because there are substitution and income effects operating in opposite directions and, if total savings are to increase, private savings must be very sensitive to the real interest rate, since it has to more than compensate for the decrease in the volume of savings previously collected by the government through the inflation tax, as well as for other negative effects that high interest rates may have on government savings.

The empirical work on the eff ect of the rate of interest on savings clearly indicates that there is no consensus among economists regarding the significance of this variable. This work follows two basic lines, some studies try to estimate the direct eff ect of interest rates on savings, and other, more recent studies follow the so-called "Euler equation" approach, specifying a relationship between the rate of change of consumption over time and the expected real interest rate. Both lines of research have generated ambiguous and unconvincing results. Empirical evidence supporting the "high interest elasticity hypothesis" for developed economics can be found in Boskin (1978), and Summers (1984). On the other hand, Howrey and Hymans (1978), and Hall (1985) find no significant eff ects. For the developing countries, Fry $(1980,1988)$ finds positive and significant values, whereas Giovannini $(1983,1985)$ finds the opposite. In a substantial study on 25 Asian and Latin American countries, Gupta (1984) concludes that generalizations about the appropriateness of raising interest rates as a means of increasing savings are not applicable. Financial conditions seem to affect savings in Asia, but not in Latin America.

\section{The Brazilian experience since the early sixties.}

The economic strategy adopted by the government that emerged from the 1964 military coup in Brazil, in addition to a series of stabilization measures designed to restore internal and external imbalances, consisted of a variety of institutional and structural reforms aimed at the modernization of the country. In the words of Roberto Campos, one of the architects of the new program: 
Perhaps the major accomplishment of the PAEG $G^{4}$ lies not so much in the attainment of specific goals as in the major concentrated effort that was made in the direction of institutional reform and modernization. Those reforms were to be economic and social (fiscal, agrarian and housing) and instrumental (banking and administrative). (Campos, 1969, pp.334).

The official diagnosis about the financial system stressed the necessity of redefining the financing methods of both the public and the private sectors. In the public sector the priority was placed on the development of a fiscal system that would make the financing of government expenditures less dependent on inflationary finance, a major characteristic of the previous expansionary period. With regard to the private sector, the official analysis indicated the necessity of strengthening the debt-asset system, creating new institutions, improving overall credit conditions and, particularly, developing medium and long-term saving instruments, yielding positive real rates of return, in order to raise new savings and divert savings from the alternative of curb markets, real estate and capital flight.

In order to redefine the financial structure of the economy a set of laws, decrees and resolutions were introduced between 1964 and 1966, suff ering subsequent modifications. The details of the reforms, as well as analyses of its outcomes, have been studied by several researchers and will not be repeated here ${ }^{5}$. For our purposes the important point is the fact that one of the main steps of the reforms was the introduction of inflation indexation in the system, mainly as a mechanism to free interest rates.

Indexation was introduced as a means of coping with the chronic inflation that plagued the Brazilian economy and seemed to be resistant to traditional monetary and fiscal policies. Among several perverse eff ects, high inflation, coupled with the limitations that the so-called Usury Law placed on nominal interest rates, was responsible for the diversion of a substantial volume of savings from the financial market. Additionally, it created incentives for the postponement of tax payments. Indexing was introduced as a device to compensate nominal returns for the changes in the price level, as a way of recovering the real value of tax revenues and as a way to stabilize the rate

${ }^{4}$ The plan which defined the economic strategy of the new government.

${ }^{5}$ See for example Sochaczewsky (1980), Gleizer (1987) and Welch (1988). 
of inflation itself. ${ }^{6}$

Despite the various aspects that distinguish the Brazilian reforms, or its outcomes, from the ones advocated by the proponents of liberalization based on the financial repression theory, some of the notions underlying the Brazilian experience are very similar to FR Theory. The formulators of the reforms were convinced that restoring market forces, "getting prices right", and raising real interest rates were some of the preconditions for increased savings, investment and sustained growth in the future. The following portion of the government analysis of the reforms and its prospects leave no doubts about it:

"In an economy suffering from high rates of inflation, where a rigorous anti-inflationary policy is being undertaken an argument in favor of high interest rates can be made. By high interest rates we mean high in relative terms, including monetary correction. The economy will derive two main benefits, besides the probable increase in savings in the first round. Since the individuals receiving the interest payments belong to the classes with higher propensities to save, there will be an "income-effect" that might lead to higher savings. In addition, higher interest rates will prevent relatively unproductive uses of capital (except those administratively selected). As monetary stabilization progresses, we can expect long term rates to return to a normal level"." (Decennial Plan, Quoted in Zini 1982 pg.74).

As a result of the reforms there was a rapid process of financial deepening in the Brazilian economy. Several non-banking financial institutions were created and there was a tremendous diversification of instruments available to the public. Table 1 illustrates some of the developments.

A well known indicator of the degree of financial deepening is the so called Goldsmith Financial Interrelation Ratio (GFIR). This indicator is defined as the ratio of non-monetary financial assets to GDP. As we can see from Table 1 on the previous page, the Brazilian GFIR jumped from $1.5 \%$ in 1960 to $13.5 \%$ in 1970 and to a level of 59.4 in 1985 . One can also observe that the ratio of total financial assets to GDP oscillated around $23 \%$, with no definite trend during

${ }^{6}$ For an early analysis of indexation in Brazil, focusing on its use as a policy tool to fight inflation, see Fishiow (1974).

${ }^{7}$ Author's translation. 
Table 1.

\begin{tabular}{cccc}
\hline Year & $\begin{array}{c}\text { Monetary } \\
\text { assets }\end{array}$ & $\begin{array}{c}\text { Non-monetary } \\
\text { assets }\end{array}$ & $\begin{array}{c}\text { Tot. financial } \\
\text { assets }\end{array}$ \\
\hline 1960 & 22.1 & 1.5 & 23.6 \\
1961 & 22.4 & 1.3 & 23.7 \\
1962 & 22.2 & 1.4 & 23.6 \\
1963 & 20.0 & 1.2 & 21.2 \\
1964 & 18.5 & 1.6 & 20.1 \\
1965 & 20.6 & 3.2 & 23.8 \\
1966 & 16.4 & 4.3 & 20.7 \\
1967 & 17.9 & 6.6 & 24.5 \\
1968 & 17.3 & 9.2 & 26.5 \\
1969 & 17.3 & 10.7 & 28.0 \\
1970 & 17.0 & 13.5 & 30.5 \\
1971 & 16.7 & 17.5 & 34.2 \\
1972 & 17.3 & 21.3 & 38.7 \\
1973 & 18.4 & 24.2 & 42.6 \\
1974 & 16.9 & 22.5 & 39.4 \\
1975 & 17.0 & 27.2 & 14.2 \\
1976 & 14.8 & 25.9 & 40.7 \\
1977 & 13.6 & 26.7 & 40.3 \\
1978 & 13.0 & 28.4 & 41.4 \\
1979 & 13.4 & 27.9 & 41.3 \\
1980 & 11.3 & 34.3 & 45.6 \\
1981 & 10.1 & 42.7 & 52.8 \\
1982 & 9.2 & 41.2 & 50.4 \\
1983 & 7.3 & 51.3 & 58.6 \\
1984 & 7.1 & 54.2 & 61.3 \\
1985 & 7.9 & 59.4 & 67.3 \\
\hline
\end{tabular}

Note: Figures as \% of GDP

Source: Central Bank of Brazil. Annual Reports.

the first decade, jumping to about $41 \%$ in the late 1970 's and to $67.3 \%$ in 1985 .

These figures indicate that the fast increase in the ratio of nonmonetary assets to GDP during the sixtics was a countcrpart of a steady decline in the share of monetary assets in the total of financial assets, as measured by thcir ratio to GDP. This seems to imply that the reforms managed to attract to the financial system savings that 


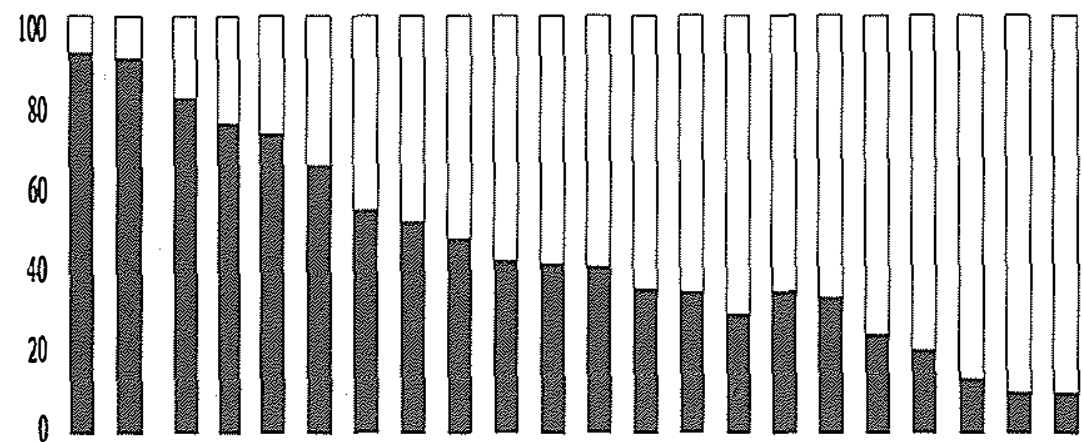

$\begin{array}{llllllllllllllllllllll}64 & 65 & 66 & 67 & 68 & 69 & 70 & 71 & 72 & 73 & 74 & 75 & 76 & 77 & 78 & 79 & 80 & 81 & 82 & 83 & 84 & 85\end{array}$

Source: Central Bank of Brazil

Graph 1.

Financial Assets Held By the Public 1964 - 1985

were ke pt in monetary form outside it.

It is also interesting to analyze the changes in the assets held by the public. The share of non-monetary assets in total assets increased from $6.4 \%$ in 1960 to $43,7 \%$ in 1970 to about $86.1 \%$ in 1985 . Saving deposits were the segment that grew at higher rates among the nonmonetary assets, from $0.3 \%$ of the total in 1967 to about $3.3 \%$ in 1970 and to $27.1 \%$ in 1985 . Time deposits and government bonds have also grown substantially. Graph 1 illustrates these developments.

The data confirms the assertion that extensive fin ancial decpening occurred in the Brazilian economy since the carly sixtics. One should be very cautious, however, when using these figures to draw conclusions about the cvolution of the cconomy's overall savings rate as well as that of its components. National accounting data shows that domestic saving as a percentage of GDP increased after the introduction of the reforms. However, private savings as a percentage of GDP was relatively insensitive to the innovations instituted, as 
the data in table 2 reveals. The main changes involved government savings, mainly in response to the contemporaneous fiscal reforms ${ }^{8}$, and to the favorable behavior of foreign savings.

This illustrates the important, but often forgotten, point that financial deepening does not necessarily imply a greater availability of credit to the private sector, nor does it imply that savings channeled to the financial system will be used to finance real investment. Alternative outcomes are the use of credit by the government to finance fiscal deficits and the channeling of funds to finance purchases of consumer durables.

Despite the introduction of indexation, controls on both deposit and lending interest rates remained in Brazil throughout the period, at varying degrees. The coexistence of financial instruments with different indexation schemes, the extensive use of subsidized credit lines, controlled rates and market determined rates, gave rise to a wide dispersion of interest rates. In any event it does not seem reasonable to characterize the Brazilian financial system as a repressed one. Legal interest rates on certain segments of the market interact with free rates generating a variety of financial investment yielding high positive real interest rates. In fact, a major policy issue in the eighties has been the difficulty to resume growth in the presence of such high rates. Ex-post rates frequently understate ex-ante rates due to unforecastable accelerations of inflation or thanks to government tampering with the relevant index. Therefore, if high real interest rates are conducive to higher savings rates the post-reforms Brazilian economy constitutes a good candidate for the observation of such an outcome.

\section{Econometric analysis.}

The main purpose of this section is to test whether the level of savings in Brazil is in fact influenced by real interest rates, as the financial repression literature described above asserts. I first estimate the responsiveness of savings, aggregate as well as private, to changes

\footnotetext{
${ }^{8}$ One should also mention the creation of various compulsory saving schemes like the Time of Service Guarantee Fund (Fundo de Garantia do Tempo de Serviço FGTS), established by Law 5.107 of September 1966, financed by an $8 \%$ payroll tax levied on all salaries subject to labor legislation, followed by PIS and PASEP in 1970 .
} 
Table 2.

\begin{tabular}{lccccc}
\hline & $60-64$ & $65-70$ & $70-74$ & $74-82$ & $82-85$ \\
\hline Inflation (WPI) ${ }^{+}$ & 82.9 & 31.3 & 20.7 & 60.9 & 178.7 \\
Ex-post Deposit rate $^{+}$ & -15.0 & 10.0 & 4.0 & -1.0 & 6.0 \\
National Saving* $^{*}$ & 16.0 & 18.7 & 18.9 & 18.5 & 15.1 \\
Domestic Saving* $^{*}$ & 16.6 & 19.6 & 19.8 & 21.0 & 20.5 \\
Government Saving $^{*}$ & 1.6 & 4.2 & 5.5 & 2.5 & -3.1 \\
Private Saving* $^{*}$ & 14.3 & 14.4 & 13.4 & 16.0 & 18.2 \\
Foreign Saving* & 0.9 & 0.4 & 3.0 & 4.6 & 2.3 \\
Gross Investment* & 16.9 & 19.1 & 21.8 & 23.2 & 17.4 \\
Net Fac. Pmts Abd. & 0.6 & 0.9 & 0.9 & 2.5 & 5.4 \\
\hline
\end{tabular}

Note: ${ }^{+}=$percent per year, ${ }^{*}=\%$ OF GDP

Sources: Conjuntura Econômica. Several issues

in real interest rates using a traditional savings function approach and then address the issue of intertemporal substitution in consumption decisions using the Euler equation method.

Before addressing the issue with formal econometric techniques it is useful to make a preliminary evaluation of the data by taking averages over the period in question. Table 2 provides us with some initial insights.

The table shows an increase in the average real deposit rate from $15 \%$ during the period $1960-64$ to $10 \%$ in $1965-70$. If we look only at the changes of the domestic saving rate we see a large increase (from $16.61 \%$ to $19.56 \%$ of GDP) over the same period. However, a look at the desegregated numbers reveals that most of this change is explained by a large increase in the government saving rate (from $1.64 \%$ to $4.24 \%$ of GDP) whereas the change in the private saving rate is very modest (from $14.3 \%$ to $14.4 \%$ of GDP). The increase in the govern ment saving rate is, certainly, more closely associated with the fiscal reform than a result of higher interest rates.

The increase of domestic savings in the seventies is again associated with higher government savings, but we should also stress the considerable rise in the role played by foreign savings (from $0.4 \%$ in 65-70 to $3.0 \%$ of GDP in the first half of the seventies). The only instance when we find private savings increasing along with real in- 
terest rates is in the first half of the eighties. However, as will be discussed later, this result is explained to large a extent by the big jump in the rate of inflation observed in the period. The table also shows the problems involved in measuring the country's saving effort by looking at national

economy that is sending about $5.5 \%$ of its GDP abroad in the form of factor payments, a point to which I will return later.

\subsection{Saving function tests.}

The standard saving function employed in the studics of interest clasticity in the development literature ${ }^{9}$ assumes the following form:

$$
\begin{aligned}
S_{d} / Y & =\beta_{0}+\beta_{1}\left(G_{y}\right)+\beta_{2}(Y)+\beta_{3}\left(i-\pi^{c}\right)+\beta_{1}\left(S_{t} / Y\right) \\
& +\beta_{5}\left(S_{d} / Y\right)_{t-1}+\varepsilon
\end{aligned}
$$

where $S_{d}$ is real domestic saving per capita, $Y$ is real GDP per capita, $i-\pi^{c}$ the ex-ante real rate of interest, $G_{y}$ the rate of growth of real output and $S_{f}$ is real forcign savings per capita (the current account deficit in the balance of payments).

Income growth is included in accordance with the life-cycle theory of savings as in Fry (1988). Many rescarchers have included the level of real per capita income as an additional explanatory variable in the savings function. While this specification is consistent with Keynes' consumption theory, it is not appropriate in a life cycle formulation in a stationary cconomy.

Foreign savings are included under the assumption that there might exist a substitution relationship between this variable and national savings. This topic has generated much controversy in the litcrature. Several authors have presented arguments and econometric tests showing that the inflow of external savings decreases domestic savings and that there is a substitution relationship between the two. Griffin (1970) argues that an increase in the inflow of forcign capital reduces domestic savings becausc: a) the government of the recipient country may change the composition of the domestic budget towards public consumption, or fiscal revenues may decrease as the government reduces taxes or makes less effort to collect them; b) the supply

${ }^{9}$ See for example Fry (1988) and Giovannini (1983a). 
of foreign resources on soft terms could reduce the saving incentives of local agents; and c) foreign resources may reduce savings when they promote consumption of imported goods.

Mikessel and Zinser (1973) in their survey conclude that there is significant agreement among researchers that saving in developing countries is negatively related to net capital imports, but that there is no agreement on the hypotheses or, in other words, on the mechanisms responsible for such behavior. Moreover, they argue that this finding may be the result of a tautological relationship between the variables. The point being that the negative relationship between external and domestic savings reported in such studies is predictable from the accounting relationships that define the variables in question and that no casual relation is implied between large capital inflows and low domestic savings in the sense that residents decide to save less. Given that national saving is equal to the excess of investment over foreign savings (i.e., the current account deficit), saving is bound to show as having fallen, as long as not all foreign in flows are invested. That is, capital imports and national saving are negatively correlated by definition. Without adequate theorizing it cannot be assumed from the regression coefficient of saving on capital imports that the inflow of foreign capital is causing a reduction in planned domestic savings. The estimated coefficient cannot distinguish between changes in the decision to save on the one hand and consumption out of foreign capital inflows on the other.

The lagged savings rate is incorporated in the regression in order to account for a multiple period adjustment process and is expected to positively affect the savings rate. Giovannini (1983a), however, calls attention to the fact that in a well specified life-cycle savings function there is little ground for such partial adjustment in saving, since saving itself is determined by a process of consumption smoothing, given the values of current income and wealth.

Finally, some measure of the real interest rate is included in the regression equation. Different approaches have been used in the literature to construct this variable.

To in vestigate the effects of in terest rates on savings in the Brazilian economy, I initially estimate savings functions analogous to equation (1). While this formulation is very similar to those used by Fry (1980) and others, some differences should be noticed. These are 
mainly related to the definition of the variables used.

First of all, the dependent variable used in the initial set of regressions to follow is the domestic savings rate, i.e. domestic savings divided by gross domestic product. Fry (1988) suggests the usc of national saving since this variable is supposed to measure a country's own efforts to mobilize resources for investment. This observation, however, secms to assume that net factor payments from abroad are positive and, therefore, national saving excceds domestic saving by that amount. In a country like Brazil where net factor payments from abroad have been negative since the early sixties, and now reach about $5.5 \%$ of GDP, the use of national saving provides a depressed view of the economy's saving effort.

Another important point is the level of aggregation involved in the choice of the dependent variable. Both the standard microeconomic discussion of income and substitution effects of changes in the interest rate and the financial repression assumption of a positive total effect relate to private (actually to household) and not to domestic (or national) saving. There is no a priori reason to expect government saving to be positively related to the real interest rate. On the contrary. In cconomies with large internal public debts, high interest rates are responsible for a large share in the reduction of government disposable income and saving, through their effects on net transfers. Some authors suggest the use of aggregate data because in flation distorts the decomposition of saving between the private and the public sector. However, the use of aggregate data induces distortions of its own. For example, financial reforms are in many circumstances accompanied by fiscal reforms and, therefore, observed changes in national saving can be the result of higher government saving which are not related to an increase in the real interest rate. The case of Brazil, as we have mentioned above, is a good example. A similar point has been made about Korea ${ }^{10}$.

Therefore, in addition to the specification with the domestic saving rate as the dependent variable, I estimate a similar model replacing it with the private saving rate ${ }^{11}$.

\footnotetext{
${ }^{10}$ See Dornbusch and Reynoso (1989)

${ }^{11}$ While the correct variable would be the household savings rate, the decompo. sition between the corporate and the household sector is not available for Brazil. Theoretical arguments claiming that "households see through the corporate veil",
} 
An additional difficulty with equation (1) is the estimation of the expected rate of inflation. To see this more clearly, note that one can write:

$r r_{t}=i_{t}-\pi_{t}^{\varepsilon}$ where,

$r r_{t}=$ the ex-ante real interest rate on the one-period bond at time $t$ : i.e., the ex ante real return from time $t$ to $t+1$.

$i_{t}=$ the nominal interest rate on the one-period bond at time $t$ :

i.e. the nominal return from time $t$ to $t+1$.

$\pi_{t}^{e}=$ the rate of inflation from time $t$ to $t+1$, expected at time $t$.

The problem with measuring the ex ante real interest rate is that expected inflation, $\pi_{t}^{e}$, is not observable and so neither is the ex-ante real in terest rate.

One modelling strategy is to use adaptive expectations, i.e. to model expected inflation as a weighted average of past inflation rates. This implies:

$$
\pi_{t}-\pi_{t-1}^{e}=\phi\left(\pi_{t-1}-\pi_{t-1}^{e}\right),(0<\phi<1),
$$

which can be written as

$$
\pi_{t}^{e}=\phi \pi_{t-1}+(1-\phi) \pi_{t-1}^{e}
$$

expanding the equation one obtains:

$$
\pi_{t}^{e}=\phi \pi_{t-1}+\phi(1-\phi) \pi_{t-2}+\ldots+\phi(1-\phi)^{n-1} \pi_{t-n}
$$

provided that:

$$
\lim _{n \rightarrow \infty}(1-\phi)_{t-n}^{n}=0
$$

Therefore, inflationary expectations are viewed as being adequately forecasted by past rates of inflation. In the tests performed below the expected inflation series was estimated using an equation of the following form:

i.e., that personal saving adjusts for changes in corporate saving, inducing a relatively constant private saving rate (David and Scadding 1974) do not seem to apply to an economy like the Brazilian where most private firms are family owned. 


$$
\pi_{t}^{e}=\phi \cdot \pi_{t}+(1-\phi) \cdot \pi_{t-1}^{e}
$$

The actual and expected inflation rates have been assumed to be equal in 1964, the period preceding the initial observation used. An itcrative procedure was used to determine the weights $(\beta)$ attached to the actual inflation rate and its previous expectation. That is, given an initial value for $\beta$, an expected inflation value was derived for each year. The values of $\pi^{\theta}$ thus generated were then used to estimate the following inverted moncy demand equation using the ordinary least squares method: $\log P_{t}=a_{0}+a_{1} \log Y_{t}+a_{2} \pi_{t}^{e}+a_{3} \log (M / P)_{t-1}+$ $\log M_{t}$, where, $Y_{t}$ is real GDP and $M_{t}$ is the actual moncy stock.

This procedure was repeated to determine the value of $\beta$ that maximizes the likelihood function of the estimated inverted moncy demand equation ${ }^{12}$.

Alternatively, we can assume that inflationary expectations are rational expectations formed. If expectations are rational, inflation forecast crrors are unforecastable given any information available at time $t$ : i.c., $E\left(\varepsilon_{t} / \Omega_{t}\right)=0$, where $E\left(\ldots / \Omega_{t}\right)$ is the mathematical cxpectations operator conditional on all information available at time $t, \Omega_{t}$.

That is, the assumption of rational expectations implics that

$$
\pi_{t}^{e}=\pi_{t, t-1}^{e}+\varepsilon_{t}
$$

where, $\varepsilon_{t}$ is uncorrelated with any information available at time $t-1$. if $\varepsilon_{t}$ were corrclated with any information available at time $t$, such information could be used to enhance the determination of $\pi_{t}^{\theta}$. An estimation strategy first suggested

by McCallum (1976) can be used in this casc. Consider the equation where the realized rate of inflation $\pi_{t}$ is used as a proxy for the expected ratc. That is,

$$
e p r r_{t}=i_{t}-\pi_{t}=r r_{t}-\varepsilon_{t}
$$

Where,

eprr $r_{t}=$ ex post real interest rate on the one period bond at time $t$ : i.c., the realized real return from time $t$ to time $t+1$.

12 This procedure is based on Coates and Khatkhate (1984). 
Table 3.

\begin{tabular}{|c|c|c|c|}
\hline & OLS & IV1 & IV2 \\
\hline$\beta_{0}$ & $\begin{array}{c}-0.208 \\
(-1.683)\end{array}$ & $\begin{array}{c}-0.343 \\
(-1.594)\end{array}$ & $\begin{array}{c}-0.347 \\
(-1.713)\end{array}$ \\
\hline$\beta_{1}$ & $\begin{array}{c}-0.006 \\
(-0.081)\end{array}$ & $\begin{array}{c}0.122 \\
(0.794)\end{array}$ & $\begin{array}{c}0.159 \\
(0.643)\end{array}$ \\
\hline$\beta_{2}$ & $\begin{array}{c}0.030 \\
(2.790)\end{array}$ & $\begin{array}{c}0.038 \\
(2.225)\end{array}$ & $\begin{array}{c}0.041 \\
(2.545)\end{array}$ \\
\hline$\beta_{3}$ & $\begin{array}{c}0.022 \\
(0.609)\end{array}$ & $\begin{array}{c}-0.080 \\
(-1.149)\end{array}$ & $\begin{array}{c}-0.006 \\
(-0.109)\end{array}$ \\
\hline$\beta_{4}$ & $\begin{array}{c}-0.257 \\
(-1.283)\end{array}$ & $\begin{array}{c}-0.030 \\
(-0.821)\end{array}$ & $\begin{array}{c}-0.360 \\
(-1.455)\end{array}$ \\
\hline$\beta_{5}$ & $\begin{array}{c}0.243 \\
(1.140)\end{array}$ & $\begin{array}{c}0.407 \\
(1.418)\end{array}$ & $\begin{array}{c}0.236 \\
(0.989)\end{array}$ \\
\hline$R^{2}$ & 0.42 & 0.15 & 0.29 \\
\hline F & 4.61 & 1.93 & 3.06 \\
\hline DW & 1.483 & 1.757 & 1.610 \\
\hline
\end{tabular}

Note: For sources and data description see appendix.

Numbers in Parentheses are $t$ statistics.

See text for description of instruments.

$\pi_{t}=$ The actual rate of inflation from $t$ to $t+1$.

Equation (1) implies that the use of equation (2) induces a classical errors in variables problem. Consistent estimates are obtainable if one can find instrumental variables correlated with the expected rate of inflation but uncorrelated with any expectational errors. Given the assumption of rationality, any information available at time $t-1$ meets this requirement. In particular lagged values of inflation are suitable instruments. Thus the rational expectations assumption is implemen ted below by using lagged values of inflation as instruments.

Table 3 summarizes the results obtained in the estimation of the equation on page 14 .

In the ordinary least squares estimation $\left(i-\Pi^{e}\right)$ is the expected real interest rate estimated by using the adaptive expectations mechanism described above. Its coefficient is rather small and is not sig- 
nificant in explaining the savings ratio, questioning the financial repression literature's emphasis on the importance of high real interest rates as a determinant of domestic saving. In fact, with the exception of the level of real per capita income none of the variables was significant in explaining the savings ratio, although the signs of the coefficients conformed to a priori expectations. As discussed above, the negative cocfficient of forcign savings is expected from the way the variable is defined and need not imply a reduction in planned domestic savings. In fact, the insignificance of this coefficient casts doubts on the substitution hypothesis encountered in the literature. The goodness of fit measure shows that about $42 \%$ of the variance of the domestic savings rate can be explained by the multiple regression equation.

Given the possible endogencity of income, its growth rate and the real interest rate, additional estimations using two stages least squares were performed. In these cases the real interest rate was cstimated according to the rational expectations hypothesis described above. The first regression (IV1) uses as instruments the following variables: the lagged level of per capita income, the lagged rate of growth of GDP, the lagged foreign savings ratio, the rate of population growth, the rate of growth of moncy lagged one and two years, the nominal interest rate, the rate of inflation lagged onc and two years, and the lagged dependent variable. In the second regression (IV2) the instruments were the rate of population growth, the level of real exports, the level of real gross investment, the lagged dependent variable and the log of the real money supply lagged one year. As we can see, the main change from the ordinary least squares results is the fact that the sign of the coefficient of the real interest rate is now negative, although in none of the regressions is it statistically significant. As in the previous casc, the only explanatory variable significant in explaining the savings ratio is the level of per capita income. According to the corrected cocfficients of determination found in the instrumental variable estimations, only $15 \%$ (for IV1) and $29 \%$ (for IV2) of the variances of the dependent variable are explained by the regression. Finally, given the use of the lagged savings ratio as an explanatory variable, the Durbin-Watson statistic can not be used to test for serial autocorrelation. The use of Durbin's $h$ statistic was also not possible for calculation reasons. Therefore, I tested for au- 
Table 4.

\begin{tabular}{|c|c|c|c|}
\hline & OLS & IV1 & IV2 \\
\hline$\beta_{0}$ & $\begin{array}{c}-0.496 \\
(-3.315)\end{array}$ & $\begin{array}{c}-0.692 \\
(-3.065)\end{array}$ & $\begin{array}{c}-0.539 \\
(-2.691)\end{array}$ \\
\hline$\beta_{1}$ & $\begin{array}{c}-0.047 \\
(-0.461)\end{array}$ & $\begin{array}{c}0.008 \\
(0.047)\end{array}$ & $\begin{array}{c}0.013 \\
(0.045)\end{array}$ \\
\hline$\beta_{2}$ & $\begin{array}{c}0.053 \\
(3.948)\end{array}$ & $\begin{array}{c}0.071 \\
(3.619)\end{array}$ & $\begin{array}{c}0.056 \\
(3.714)\end{array}$ \\
\hline$\beta_{3}$ & $\begin{array}{c}-0.015 \\
(-0.375)\end{array}$ & $\begin{array}{c}-0.064 \\
(-0.941)\end{array}$ & $\begin{array}{c}-0.024 \\
(-0.430)\end{array}$ \\
\hline$\beta_{4}$ & $\begin{array}{c}-0.843 \\
(-3.546)\end{array}$ & $\begin{array}{c}-1.229 \\
(-3.315)\end{array}$ & $\begin{array}{c}-0.872 \\
(-3.551)\end{array}$ \\
\hline$\beta_{5}$ & $\begin{array}{c}0.235 \\
(0.991)\end{array}$ & $\begin{array}{c}0.149 \\
(0.548)\end{array}$ & $\begin{array}{c}0.274 \\
(0.818)\end{array}$ \\
\hline$R^{2}$ & 0.53 & 0.44 & 0.51 \\
\hline F & 6.56 & 4.97 & 6.37 \\
\hline DW & 1.626 & 1.880 & 1.709 \\
\hline
\end{tabular}

Note: For sources and data description see appendix.

Numbers in Parentheses are t statistics.

tocorrelation by using a $t$ test on the serial correlation coefficient of the unconditional residuals. In none of the cases I could reject the hypothesis that this coefficient is zero, i.e. that serial correlation is absent.

As mentioned previously the presumed positive effect of higher interest rates should operate on household savings and not on aggregate domestic savings. Given the unavailability of data on household savings in Brazil, equation (1) was reestimated using the private savings ratio as the dependent variable, replacing the domestic savings ratio. The results are summarized in table 4.

The results are similar to those obtained in the regressions using the domestic saving ratio as the dependent variable. Per capita income positively and significantly affects the private saving ratio. The real rate of interest remains insignificant, but the coefficients are now negative in all the regressions. The main change is the fact that now 
foreign savings pick a negative sign and the variable is statistically significant. Besides the caveats raised in relation to the meaning of such a result in the regression relating domestic saving and foreign saving, some authors have argued that the foreign saving ratio does not belong in the regression with the private saving ratio as the dependent variable. For example, de Melo and Tybout (1986) argue that:

"In a world of integrated capital markets, economic agents optimize over their present and future consumption of both domestic and foreign goods, taking interest rates, exchange rates, income and expectations into consideration. Hence, given that the level of foreign savings is simply the current account deficit, a better specification of the savings function for an open economy might exclude foreign savings and include the real exchange rate. "(de Melo and 7ybout, 1986 pg. 571).

The relevance of such specification is not clear for the Brazilian economy, since its institutional characteristics contradict the assumption of large world integration that underlies the model. The country is closed both on trade and capital accounts. The limitations imposed on imported consumption goods and on the holdings of foreign assets make the assumption of intertemporal consumption optimization over foreign goods and the inclusion of foreign assets at least questionable. Tentative results obtained in the estimation of private savings functions using the real exchange rate as opposed to the foreign saving ratio as an explanatory variable were extremely poor and seem to indicate misspecification problems.

\subsection{Euler equation tests.}

As a result of Robert Lucas's (1976) influential critique of econometric policy analysis the study of consumption and saving was profoundly affected. The argument held that changes taking place in the economy mainly, but not exclusively, as a result of policy variations, imply that the relationship between consumption, income and interest rates might not be stable over time. That is, the traditional consumption function is not invariant to policy changes nor to shif ts taking place elsewhere in the economy. Therefore, the very existence of a consumption function was questioned. Robert Hall (1978) soon suggested a new approach to study consumption that could overcome the problems raised by Lucas. The main idea is that consumption 
should be modelled according to optimizing principles, where forward looking agents choose their level of consumption in order to maximize expected Iifetime utility, given all available information about current and future income and prices.

Regarding the role of the interest rate in the determination of consumption (or saving) decisions, the approach attempts to estimate parameters of the representative agent's utility function, which are viewed as the invariant structural relationships, rather than parameters of the consumption or savings function. The main idea is, in Hall's words, that:

"Consumers plan to change their consumption from one year to next by ars amount that depends on their expectations of real interest rates. Ac ual movements of consumption differ from planned movements by a completely unpredictable random variable that indexes all the information available next year that was not incorporated in the planning year the year before. If expectations of real interest rates shift, then there should be a corresponding shift in the rate of change of consumption. The magnitude of the response of consumption to a change in real interest expectations measures the intertemporal elasticity of szebstitution." (Hall, 1981, pg.2)

Formally, the representative consumer secks to maximize:

$$
E_{t} \sum_{s=0}^{N}(1+\delta)^{-s} \cup\left(C_{t+s}\right), \cup^{\prime}>0, \cup^{\prime \prime}<0
$$

s.t.

$$
\sum_{s=0}^{N}(1+r)^{-s}\left(C_{t+s}-W_{t+s}\right)=A_{t} .
$$

where $C$ is consumption, $E_{t}$ is the expectation conditional on all information available at time $t, \delta$ is the subjective rate of time prefcrence, $\cup(\cdot)$ is the one period utility function, $r$ is the real interest ratc, $W$ is earnings on sources other than savings and $A$ stands for assets apat from human capital. Summation is from $n=0$ to $N$.

The first order condition necessary for an optimum is given by the followi ng Euler equation:

$$
E_{t} \cup^{\prime}\left(C_{t+1}\right)=[(1+\delta) /(1+r)] \cup^{\prime}\left(C_{t}\right)+\varepsilon_{t}
$$


which asserts that marginal utility next period is expected to be the same, up to a constant multiple ${ }^{13}$, as today's marginal utility.

Under the assumptions of equality between $\delta$ and $r$ and linearity of marginal utility ${ }^{14}$ we can obtain Hall's famous random walk result:

$$
C_{t+1}=C_{t}+\varepsilon_{t}
$$

where $\varepsilon_{t}$ is a rational forecast error.

Hall (1978), and others after him, tested the theory by placing additional lagged variables on the right hand side, regressing the change in consumption on them, and computing $t$ or $F$ tests for their exclusion, i.e., by testing whether the change in consumption was forecastable.

The random walk result thus derived is based on the assumption that the real interest rate is constant over time. If the real interest rate is allowed to change the log-linear version of the consumer's Euler equation is: ${ }^{15}$

$$
\log \left(C_{t+1} / C_{t}\right)=\mu+\sigma r_{t}+\varepsilon_{t}
$$

where $\sigma$ is the intertemporal elasticity of substitution, measuring the percentage reduction in this period's consumption, caused by a $1 \%$ increase in $r_{t}$, the expected real rate of interest. $\mu$ is a constant that depends on the variances and covariances of $\log \left(C_{t+1} / C_{t}\right)$ and $r_{t} \cdot \varepsilon_{t}$ is an error term which may be correlated with $r_{t}$ but is uncorrelated with lagged variables. The equation says that a high ex-ante real interest rate leads to a rapid growth in consumption, i.e., to low consumption today relative to future consumption. In accordance with the random walk model, where no variable known at time $t$ should help predict the rate of consumption growth, the model with a varying real interest rate implies that the latter is the only variable that should help forecast the rate of growth of consumption. Equation (1) can be estimated using instrumental variables. Any lagged variable is a candidate for an instrument, since it is orthogonal to $\varepsilon_{t}$. Of course, good instruments must be correlated with the expected real interest rate.

${ }^{13}$ In this derivation the real interest rate is assumed to be constant.

${ }^{14}$ One can obtain the random walk result with other approximations as well.

${ }^{15}$ See Hall (1981) for the derivation. 
Table 5.

$\log \left(C_{t+1} / C_{t}\right)=\mu+\sigma r_{t}+\varepsilon_{t}$

\begin{tabular}{lcccc}
\hline & OLS & IV1 & IV2 & IV3 \\
\hline$\mu$ & 0.053 & 0.053 & 0.053 & 0.053 \\
& $(4.287)$ & $(4.123)$ & $(4.049)$ & $(4.194)$ \\
$\sigma$ & 0.319 & 0.329 & 0.309 & 0.331 \\
& $(2.829)$ & $(1.843)$ & $(1.640)$ & $(2.111)$ \\
$A R^{2}$ & 0.219 & 0.219 & 0.219 & 0.219 \\
$\mathrm{DW}$ & 1.817 & 1.819 & 1.815 & 1.819 \\
$\mathrm{~F}$ & 8.005 & 7.992 & 7.996 & 7.990 \\
\hline
\end{tabular}

Note: For and sources see appendix A., Numbers in parentheses are $t$ statistics.

Table 5 summarizes the results obtained in the estimation of equation (1) for Brazil from 1960 to 1985 . Consumption is normalized by population and is deflated by the CPI. It is important to point out that the measurc of consumption used in the econometric tests is total consumption spending, as published in the Brazilian National Accounts. This measure includes spending on consumer durables, which many researchers consider closer to investment rather than to consumption. The theoretically appropriate variable should be consumer's spending on non-durable goods and services of consumer durable goods. Given the unavailability of such data for Brazil, this distinction is disregarded in the econometric tests performed below. The real interest rate is the one paid by first line finance companies on bills of exchange. In addition to OLS, the table reports the results obtained with three sets of instrumental variables. IV1 includes the lagged dependent variable, inflation lagged one and two periods and the log of money supply growth lagged one and two periods. IV2 drops the lagged dependent variable from IV1 and IV3 is simply IV1 plus the trend variable.

The coefficients obtained for the rcal interest rate imply fairly small elasticities in all the regressions, between 0.00309 and 0.00331 , indicatin $\mathrm{g}$ that consumers are very reluctant to postpone consumption in response to a higher expected real interest rate. In other words, saving is not responsive to higher interest rates. The coeffi- 
Table 6.

$$
\log \left(C_{t+1} / C_{t}\right)=\mu+\sigma r_{t}+\varepsilon_{t}
$$

\begin{tabular}{lcccc}
\hline & OLS & IV1 & IV2 & IV3 \\
\hline$\mu$ & 0.073 & 0.083 & 0.083 & 0.083 \\
& $(3.447)$ & $(3.490)$ & $(3.476)$ & $(3.579)$ \\
$\sigma$ & 0.300 & 0.496 & 0.494 & 0.492 \\
& $(1.506)$ & $(1.825)$ & $(1.797)$ & $(1.992)$ \\
$A R^{2}$ & 0.083 & 0.004 & 0.006 & 0.007 \\
DW & 1.627 & 1.647 & 1.647 & 1.647 \\
\hline
\end{tabular}

Note: For data and sources see appendix A.

Numbers in parentheses are $\ell$ statistics.

cients found in the OLS, IV1 and IV3 estimations are significantly different from zero at the $95 \%$ confidence level, whereas the one found in the IV2 estimation is less precise, being significant only at $89 \%$ confidence levels. The adjusted coefficient of determination indicates that, for all the regressions, the independent variable explains about $22 \%$ of the variation in the rate of growth of consumption. According to the Durbin-Watson d statistic there is no evidence of serial correlation in any of the regressions in table 5.

Another set of tests involved the use of the real return on treasury bills as a measure of the real interest rate. The main problem with these data is the shorter range of the series. Data are available for the period after 1971 only. On the other hand these data is considered the most reliable available in Brazil, as described in the appendix. The results of the tests using the rate of return on LTN's are depicted in table 6 , on the next page.

Whereas the size of the interest rate coefficient turns out to be larger than above, about 0.49 , it remains small and the results are poorer in terms of significance of the individual estimates, goodnessof-fit and overall significance, as implied by the low $F$ statistics reported.

\section{Conclusions.}

This essay discussed the role of the interest rate in the determination of domestic and private savings in Brazil from 1965 to 1985. 
The results obtained in the econometric tests performed, both in the savings function and in the Euler equation approaches, confirm the insights derived from the correlation exercises, that domestic savings in general, and private savings in particular, respond negligibly to real interest rates in Brazil. One is, therefore, led to conclude that neither theory nor empirical evidence offer support for a policy of high interest rate as a mechanism to increase the savings rate.

As discussed above, such findings are in contradiction with the crucial assumption that permeates the whole financial repression literature, namely, that savings are very sensitive to real interest rates and that, as a result, the latter has a strategic role in mobilizing savings and fomenting economic development.

Moreover, as the analysis of the evolution of savings in Brazil clearly illustrates, high interest rates have a perverse eff ect on government savings, because of their impact on domestic debt service, which in turn reduces the public sector's ability to finance its investments with no pressures on the financial system. Given the complementarities between public and private investment spending, that characterize developing economies, and the evidence that in economies with underdeveloped stock markets firms rely primarily on retained profits and bank loans for capital expansion, a policy of high interest rates reduces private investment spending through a complex crowding out process.

Of course, this is not an argument against fully exploiting the opportunities associated with well functioning financial markets, nor a case for keeping real interest rates negative and financial markets "repressed". Moderately positive real interest rates enforce rationality in investment project selection and deter financial disintermediation. Gains in output growth of an order of $1 / 2$ of a percentage point per percentag $\&$ point increase in real interest rates, however, are definitely not feasible. Moreover, policies of interest controls should be studied in the context of the global development strategies of which they are a part, and not in isolation. The focus on high interest rates as a powerful prescription to increase savings, investment and growth is, nevertheless, misplaced and in many instances self-defeating.

\section{Data appendix}

Following are brief definitions of the data series used above, with 
the corresponding sources:

$S_{d} / Y$ : Domestic savings as a proportion of GDP, in current prices, from the Brazilian National Accounts, by Instituto Brasileiro de Geografia e Estatistica (IBGE). Domestic savings equal national savings plus net factor payments sent abroad.

$S_{p} / Y$ : Private savings as a proportion of GDP, in current prices, from the Brazilian National Accounts. Private savings are calculated by deducting government savings from national savings. Note that state owned enterprises are included in the private sector in the national accounts.

$S_{f} / Y$ : Foreign savings as a proportion of GDP, defined as the current account deficit in the balance of payments. From national accounts, IBGE.

$C$ : Total consumption spending from the Brazilian National Accounts, IBGE.

$G_{y}:$ Rate of growth of real GDP, IBGE.

$Y$ : Natural logarithm of real GDP per capita. Defined as GDP in current prices, deflated by the CPI and normalized by end of year population.

$i_{1}$ : Nominal rate of return paid by first line Finance Companies to holders of Bills of Exchange. The rates are annualized from the average monthly rate. Data from 1960 to 1978 are from Annual Report of the Central Bank of Brazil, Table 1.28, various issues. From 1978 onwards the source is Revista Analise. Interest rates are expressed in proportional terms in all the regressions.

$i_{2}$ : Nominal rate of return on 91 days Treasury Bills, calculated from the rate of discount by the use of the following expression:

$$
i_{2 \text { (Monthly) }}=\left[(1-d i s c \times 91 / 360)^{-360 / 91}\right]-1
$$

This series is available from FGV (1987) and the rates used are the effective annualized rates calculated from $i_{2 \text { (monthly). }}$

$\pi$ : rate of inflation on the wholesale price index (WPI), from Estatisticas Historicas do Brasil, IBGE.

$\pi^{. e}$ : Expected rate of inflation. See text for computation methodology.

$(i-\pi)_{t}=r_{t}$ : Real ex-post interest rates, calculated as $(i-\pi) /(1+$ $\pi)]^{*} 100$.

$\left(i-\pi^{e}\right)_{t}$ : Real ex-ante interest rates, calculated as $\left[\left(i-\pi^{e}\right) /(1+\right.$ $\left.\left.\pi^{e}\right)\right]^{*} 100$. 
$R R$ : Real effective exchange rate index, weighted average of wholesale prices of main trading partners/domestic wholesale prices, $1977=100$. IMF, IFS.

\section{References}

Arida, P. and Lara-Resende, A. Recession and the Rate of Interest: The Brazilian Economy in the 1980's. Working Paper No. 63. Catholic University, Rio de Janeiro, 1985.

Boskin, M. Taxation, Saving and the Rate of Interest. Journal of Political Economy, 86:3-27, 1978.

Theoretical and Empirical Issues in the Measurement, Evaluation, and Interpretation of Postwar U.S. Saving in Adams, F. and Susan Wachter, (eds.). Savings and Capital Formation Lexington Books, Lexington, 1986.

Campos, R. O. Retrospect over Brazilian Development Plans in Howard Ellis, (cd.). The Economy of Brazil University of California Press, 1969.

Coats Jr., W. and D. Khatkhate. Monetary Policy in Less Developed Countrics: Main Issues. The Developing Economies, 4, XXII, Dec: 329-48, 1984.

Corden, M. W. The Relevance for Developing Countries of Recent Developments in Macroeconomic Theory, The World Bank, Development Policy Issues Series, Report No. VPERS5. 1986.

David, P. and John Scading. Private Saving, Ultrarationality, Aggregation and 'Denison's Law. Journal of Political Economy, 82: 225-249, 1974.

De Melo, J. and J. Tybout. The effects of Financial Liberalization on Savings and Investment in Uruguay. Economic Development and Cultural Change, 34 no. 3 April: 1986.

Deaton, A. Saving in Developing Countries, Research Program in Development Studies, Discussion Paper \# 144, Woodraw Wilson School, Princeton University. 1989.

Diaz-Alejandro, C. Good-Bye Financial Repression, Hello Financial Crash. Journal of Development Economics, 19(1-2): 1-24, 1985. Dornbusch, R. and Reynoso, A. Financial Factors in Economic Development NBER Working Paper \# 2889. Cambridge, MA., 1989.

Fishlow, A. Indexing Brazilian Style: Inflation Without Tears? Brooking Papers on Economic Activity, 1. 1974. 
and Morley, S Instability and Stabilization in High Interest Economies, mimeo, U.C. Berkeley. 1985.

Fry, M. Saving, Investment, Growth and the Cost of Financial Repression. World Development, 8(4):317-27, 1980.

Models of Financially Repressed Developing Economies. World Development, 10(9): 731-50, 1982.

Money, Interest, and Banking in Economic Development, The John Hopkins Univ. Press, Baltimore. 1988.

Galbis, V. Financial Intermediation and Economic Growth in Less-Developed Countries: A Theoretical Approach. Journal of Development Studies, 13(2): 58-72, 1979.

Gersovitz, M. Saving and Development, Research Program in Development Studies, Discussion Paper \# 131, Woodrow Wilson School, Princeton University. 1987.

Giovanini, A. The Interest Elasticity of Savings in Developing Countries: The Existing Evidence. World Development, 11(7):601, 1983.

Saving and the Real Rate of Interest in LDC's. Journal of Development Economics, 18 (2-3): 197-217, 1985.

Gleizer, D. Financial Intermediation in Brazil, mimeo, U.C. Berkeley. 1987.

Goldsmith, R. Desenvolvimento Financeiro Sob Um Século de Inflação: Brasil 1850-1984, Harper \& Row do Brasil, São Paulo. 1986.

Griffin, R. Foreign Capital, Domestic Savings and Economic Development. Oxford Bulletin of Economics and Statistics, 32: 99-112, 1970.

Gupta, K. Finance and Economic Growth in Developing Countries. London, Croom Helm, 1984.

Hall, R. Stochastic Implications of the Life Cycle-Permanent Income Hypothesis: Theory and Evidence. Journal of Political Economy, 86: 971-88, Dec, 1978.

Real Interest and Consumption, NBER Working Paper No 1694. 1985.

Intertemporal Substitution in Consumption. Journal of Political Economy, 86 no. 21:339-57, 1988.

Howrey, E. and Hymans, S. The Measurement and Determination of Loanable-Funds Saving. Brookings Papers on Economic Activity 
No. 3, 655-85, 1978.

Kapur, B. Alternative Stabilization Policies in Less Developed Economies. Journal of Political Economy, 84 No. 4:1976.

King, M. The Economics of Saving: A Survey of Recent Contributions, in Arrow, K. and Honkapohja, S., (Eds.). Frontiers of Economics Blackwell, Oxford, 1985.

Lucas Jrr., R. E. Econometric Policy Evaluation: A Critique, in K. Brunner and A. Meltzer (eds.) The Phillips Curve and Labor Markets Vol. 1 in the Carnegie-Rochester Conference Series on Public Policy, North Holland. 1976.

McCallum, B. T. Rational Expectations and the Natural Rate Hypothesis: Some Consistent Estimates. Econometrica, 44 No. 1, January: 1976.

Mckinnon, R. Money and Capital in Economic Development Brookings, Institution, Washington, D.C. 1973.

Financial Policies, in. Policies for Industrial Progress in Developing Countries John Cody et. all. (eds.), Oxford University Press, London, 1980.

Mikesell, R. and Zinser, J. The Nature Of the Savings Function in Developing Countries: A Survey of the Theoretical and Empirical Literature. Journal of Economic Literature, 11(1): 1-26, 1973.

Mishkin, F. Understanding Real Interest Rates, NBER Working Paper No. 2691. 1988.

Modigliani, F. Life Cycle, Individual Thrift, and the Wealth of Nations. American Economic Review, 76(6): 297-313, 1986.

Papanek, G. The effects of Foreign Aid on Domestic Savings. Economic Journal, 82 No. 327(9): 1972.

Shaw, E. Financial Deepening in Economic Development. Oxford University Press, New York. 1973.

Siegel, J. Inflation-Induced Distortions in Government and Private Saving. Review of Economic and Statistics April, 85-90, 1979.

Sochaczewsky, A.C. Financial and Economic Development of Brazil, 1952- 1968, Unpub. Ph.D. Dissertation, The London School of Economics and Political Science. 1980.

Summers, L. The After-Tax Rate of Return Aff ects Private Savings. American Economic Review, 74(5):249-53, 1984.

Tavares, M. C. et all. A Questão da Poupança: Desfazendo Confusões in Tavares, M. C. and David M.. A Economia Política da Crise 
Vozes Ed., Rio de Janeiro, 1982.

Taylor, L. Structuralist Macroeconomics: Applicable Models for the Third World, Basic Books, New York. 1983.

Van Wijnbergen. Interest Rate Management in LDC's. Journal of Monetary Economics, 12(3):433-52, 1983a.

Credit Policy, Inflation and Growth in a Financially Repressed Economy. Journal of Development Economics, 13(1-2): 45-65, 1983 b.

Welch J. Capital Markets in the Development Process: The Case of Brazil, Unpublished Ph. D. Dissertation, University of Illinois at Urbana-Champaingn. 1988. 